\title{
Body fat measurements using bioelectrical impedance in pediatric patients treated with hematopoietic cell transplantation
}

Pomiary tkanki tłuszczowej z zastosowaniem bioimpedancji elektrycznej u dzieci leczonych przeszczepieniem komórek krwiotwórczych

\author{
${ }^{1}$ Wojciech Strojny, ${ }^{2}$ Dorota Drożdż, ${ }^{1}$ Kinga Klus-Kwiecińska, ${ }^{1}$ Danuta Pietrys, ${ }^{1}$ Walentyna Balwierz, \\ ${ }^{1}$ Szymon Skoczeń
}

${ }^{1}$ Department of Oncology and Hematology, Institute of Pediatrics, Jagiellonian University Medical College, Kraków, Poland '2Department of Nephrology and Hypertension/Renal Dialysis Unit, Institute of Pediatrics, Jagiellonian University Medical College, Kraków, Poland

${ }^{1}$ Klinika Onkologii i Hematologii Dziecięcej, Instytut Pediatrii, Uniwersytet Jagielloński, Collegium Medicum, Kraków ${ }^{2}$ Klinika Nefrologii i Nadciśnienia Tętniczego/Stacja Dializ, Instytut Pediatrii, Uniwersytet Jagielloński, Collegium Medicum, Kraków

\begin{abstract}
Introduction. In patients who have undergone hematopoietic cell transplantation (HCT), the metabolic syndrome may develop without obesity defined by Body Mass Index (BMI). Aim of the study. The aim of the study was to compare body fat parameters measured using bioelectrical impedance (BIA) and using standard parameters of obesity in patients treated with $\mathrm{HCT}$ and healthy controls. Material and methods. We compared body fat (BF) and body fat percentage (BF\%) measured using BIA in 44 patients before HCT and 28 patients after HCT, versus 26 controls. We also compared BMI and other BIA parameters in these groups of patients. Results. The differences in BF and BF\% between the patients before HCT and controls were not significant, while both BF and $\mathrm{BF} \%$ were significantly lower in patients after HCT than in the control group. No significant differences in standard clinical obesity parameters were found in the patients before HCT, and in the patients after HCT, compared with the controls. The differences in other BIA parameters between the patients before HCT and the controls were not significant, while in the patients after HCT some parameters were significantly lower. Conclusion. Significant differences in BF and BF\% in the patients after HCT compared with healthy controls suggest that BIA may be useful in screening for body fat abnormalities in patients after HCT.
\end{abstract}

Key words

bioelectrical impedance, metabolic syndrome, obesity, transplantation

\begin{abstract}
Streszczenie
Wprowadzenie. U pacjentów po przeszczepieniu komórek hematopoetycznych (hematopoietic cell transplantation - HCT) może dojść do rozwoju zespołu metabolicznego bez otyłości definiowanej na podstawie wskaźnika masy ciała (body mass index - BMI). Cel pracy. Celem pracy było porównanie parametrów tkanki tłuszczowej mierzonych metodą bioimpedancji elektrycznej (bioelectrical impedance - BIA) i standardowych parametrów otyłości u pacjentów leczonych HCT i zdrowych dzieci z grupy kontrolnej. Materiał i metody. Porównywano zawartość tkanki tłuszczowej (body fat - BF) i procentową zawartość tkanki tłuszczowej (body fat percentage - BF\%) mierzone za pomocą BIA u 44 pacjentów przed HCT i 28 pacjentów po HCT, a także u 26 dzieci z grupy kontrolnej. Porównano również BMI i inne parametry BIA w powyższych grupach pacjentów. Wyniki. Różnice wartości BF i BF\% pomiędzy pacjentami przed HCT i grupą kontrolną nie były istotne statystycznie, natomiast wartości zarówno BF jak i BF\% były istotnie mniejsze u pacjentów po HCT w porównaniu z grupa kontrolna. Nie stwierdzono istotnych różnic w odniesieniu do standardowych klinicznych parametrów otyłości u pacjentów przed HCT ani u pacjentów po HCT, w porównaniu z grupą kontrolną. Różnice pozostałych parametrów BIA pomiędzy pacjentami przed HCT i grupą kontrolną nie były istotne statystycznie, natomiast u pacjentów po HCT wartości niektórych parametrów były istotnie niższe. Wnioski. Istotne statystycznie różnice w zakresie BF i BF\% pomiędzy pacjentami po HCT i zdrowymi
\end{abstract}


dziećmi z grupy kontrolnej sugerują, ze BIA może być użyteczną metodą badania przesiewowego pod kątem nieprawidłowości tkanki tłuszczowej u pacjentów po HCT.

\section{Słowa kluczowe}

bioimpedancja elektryczna, zespół metaboliczny, otyłość, przeszczepienie

\section{Introduction}

The metabolic syndrome (MetS) is one of the known late complications of hematopoietic cell transplantation (HCT), although the precise mechanisms of its development in patients treated with HCT are still unknown [1,2]. Obesity defined in terms of body mass index (BMI) is one of the components of MetS [3-6]. However, patients after HCT may have evidence of the increase in body fat or its abnormal distribution despite normal BMI [7]. Therefore, measurements of body fat may be a potential method for screening for MetS in patients after HCT. Bioelectrical impedance (BIA) is a safe, noninvasive diagnostic technique that may be used as such screening method [8].

\section{Aim of the study}

The aim of the study was to assess the usefulness of BIA as a diagnostic method in patients treated with HCT. For this purpose we compared body fat parameters measured using $\mathrm{BIA}$ with standard clinical parameters of obesity based on BMI in patients before and after HCT and in healthy controls.

\section{Material and methods}

\section{Patients}

We conducted a prospective study including pediatric patients referred for HCT in the Stem Cell Transplantation Center of the University Children's Hospital, Kraków, Poland, and then followed up in the outpatient clinic from June 2009 to August 2012. The group assessed before HCT consisted of
44 patients (31 boys and 13 girls; median age 9.7 years, SD 5.3 years). All measurements were performed before the start of conditioning procedure in clinically stable patients receiving no intravenous fluids, corticosteroids, or any other agents that may have interfered with fluid volume or fat parameters. The group assessed after HCT consisted of 28 patients from the former group who remained in the follow-up after the procedure (21 boys and 7 girls, median age 10.1 years, SD 5.1 years). Measurements after HCT were performed after a median of 6 months in clinically stable patients receiving no intravenous fluids, corticosteroids, or any other agents that may have interfered with fluid volume or fat parameters. The reasons for some patients of not being followed up were death during or after the procedure or not reaching the pre-specified interval between HCT and the time of the completion of the study protocol. The control group consisted of 26 healthy children (11 boys and 15 girls, median age 12.7 years, SD 4.2 years) with negative medical history and no features of acute or chronic disease at present.

The aim of the study was to compare body fat parameters measured using BIA with standard clinical parameters of body weight in patients treated with HCT and healthy controls, as well as to compare other BIA parameters in these groups of patients, and to assess the usefulness of BIA in this setting.

\section{Parameters}

We measured Body Fat (BF) and Body Fat Percentage (BF\%) using BIA and compared them with standard clinical indicators of the body contents of adipose tissue: BMI, BMI Percentiles (BMIPerc), and BMI standard deviation (BMISDS) in patients before HCT, patients after HCT, and healthy controls. We also compared other BIA parameters: total body water (TBW), lean body mass (LBM) and extracellular water

Table I. Mean values and standard deviations (SD) of body fat parameters measured using BIA in patients before HCT and healthy controls

Tabela I. Wartości średnie i odchylenia standardowe (SD) parametrów tkanki tłuszczowej u pacjentów przed HCT i zdrowych dzieci z grupy kontrolnej

\begin{tabular}{llll}
\hline $\begin{array}{l}\text { Parameter } \\
\text { Parametr }\end{array}$ & $\begin{array}{l}\text { Before HCT } \\
\text { Przed HCT }\end{array}$ & $\begin{array}{l}\text { Healthy controls } \\
\text { Zdrowi }\end{array}$ & $\begin{array}{l}\text { P value } \\
\text { Pd }\end{array}$ \\
\hline BF $(\mathrm{kg})$ & $11.8[$ SD 17.9] & $12.2[$ SD 8.03] & 0.912 \\
\hline BF\% & $18.6[$ SD 14.8] & $21.3[$ SD 8.23] & 0.389 \\
\hline
\end{tabular}

BF - (body fat) zawartość tkanki tłuszczowej; BF\% (body fat percentage) procentowa zawartość tkanki tłuszczowej; BIA (bioelectrical impedance) bioimpedancja elektryczna; HCT (hematopoietic cell transplantation) przeszczepienie komórek krwiotwórczych; SD (standard deviation) odchylenie standardowe 
Table II. Mean values and standard deviations (SD) of body fat parameters measured using BIA in patients after HCT and healthy controls

Tabela II. Wartości średnie i odchylenia standardowe (SD) parametrów tkanki tłuszczowej u pacjentów po HCT i zdrowych dzieci z grupy kontrolnej

\begin{tabular}{llll}
\hline $\begin{array}{l}\text { Parameter } \\
\text { Parametr }\end{array}$ & $\begin{array}{l}\text { After HCT } \\
\text { Po HCT }\end{array}$ & $\begin{array}{l}\text { Healthy controls } \\
\text { Zdrowi }\end{array}$ & $\begin{array}{l}\text { P value } \\
\text { P }\end{array}$ \\
\hline BF $(\mathrm{kg})$ & $6.29[$ SD 5.26] & 12.2 [SD 8.03] & 0.008 \\
\hline BF\% & $14.9[$ SD 9.12] & 21.3 [SD 8.23] & 0.017 \\
\hline
\end{tabular}

BF - (body fat) zawartość tkanki tłuszczowej; BF\% (body fat percentage) procentowa zawartość tkanki tłuszczowej; BIA (bioelectrical impedance) bioimpedancja elektryczna; HCT (hematopoietic cell transplantation) przeszczepienie komórek krwiotwórczych; SD (standard deviation) odchylenie standardowe

Table III. Mean values and standard deviations (SD) of BMI and BMI-related parameters in patients before HCT and healthy controls

Tabela III. Wartości średnie i odchylenia standardowe (SD) BMI i parametrów związanych z BMI u pacjentów przed HCT i zdrowych dzieci z grupy kontrolnej

\begin{tabular}{llll}
\hline $\begin{array}{l}\text { Parameter } \\
\text { Parametr }\end{array}$ & $\begin{array}{l}\text { Before HCT } \\
\text { Przed HCT }\end{array}$ & $\begin{array}{l}\text { Healthy controls } \\
\text { Zdrowi }\end{array}$ & $\begin{array}{l}\text { Pvalue } \\
\text { BMI }\left(\mathrm{kg} / \mathrm{m}^{2}\right)\end{array}$ \\
\hline BMIPerc & $19.0[\mathrm{SD}$ 4.21] & $20.5[$ SD 4.42] & 0.171 \\
\hline BMISDS & $61.3[$ SD 31.1] & $67.3[$ SD 27.6] & 0.406 \\
\hline
\end{tabular}

BMI - (body mass index) wskaźnik masy ciała; BMIPerc (body mass index percentile) percentyle wskaźnika masy ciała; BMISDS (body mass index standard deviation score) odchylenia standardowe wskaźnika masy ciała; HCT (hematopoietic cell transplantation) przeszczepienie komórek krwiotwórczych; SD (standard deviation) odchylenie standardowe

Table IV. Mean values and standard deviations (SD) of BMI and BMI-related parameters in patients after HCT and healthy controls Tabela IV. Wartości średnie i odchylenia standardowe (SD) BMI i parametrów związanych z BMI u pacjentów po HCT i zdrowych dzieci z grupy kontrolnej

\begin{tabular}{|c|c|c|c|}
\hline Parameter & After HCT & Healthy controls & $P$ value \\
\hline Parametr & Po HCT & Zdrowi & $p$ \\
\hline $\mathrm{BMl}\left(\mathrm{kg} / \mathrm{m}^{2}\right)$ & 18.3 [SD 3.47] & 20.5 [SD 4.42] & 0.054 \\
\hline BMIPerc & 53.0 [SD 35.4] & 67.3 [SD 27.6] & 0.108 \\
\hline BMISDS & 0.37 [SD 1.26] & 0.71 [SD 0.84] & 0.263 \\
\hline
\end{tabular}

$\mathrm{BMI}$ - (body mass index) wskaźnik masy ciała; BMIPerc (body mass index percentile) percentyle wskaźnika masy ciała; BMISDS (body mass index standard deviation score) odchylenia standardowe wskaźnika masy ciała; HCT (hematopoietic cell transplantation) przeszczepienie komórek krwiotwórczych; SD (standard deviation) odchylenie standardowe 
Table V. Mean values and standard deviations (SD) of body water parameters measured using BIA in patients before HCT and healthy controls

Tabela V. Wartości średnie i odchylenia standardowe (SD) parametrów gospodarki wodnej u pacjentów przed HCT i zdrowych dzieci z grupy kontrolnej

\begin{tabular}{llll}
\hline $\begin{array}{l}\text { Parameter } \\
\text { Parametr }\end{array}$ & $\begin{array}{l}\text { Before HCT } \\
\text { Przed HCT }\end{array}$ & $\begin{array}{l}\text { Healthy controls } \\
\text { Zdrowi }\end{array}$ & $\begin{array}{l}\text { P value } \\
\text { PCT }\end{array}$ \\
\hline TBW & $22.4[$ SD 9.07] & $26.8[9.10]$ & 0.114 \\
\hline LBM $(\mathrm{kg})$ & $30.6[$ SD 12.6] & $37.1[$ SD 13.4] & 0.105 \\
\hline ECW & $13.7[$ SD 14.8] & $13.3[$ SD 5.25] & 0.886 \\
\hline
\end{tabular}

ECW (extracellular water) woda zewnątrzkomórkowa; HCT (hematopoietic cell transplantation) przeszczepienie komórek krwiotwórczych; LBM (lean body mass) beztłuszczowa masa ciała; SD (standard deviation) odchylenie standardowe; TBW (total body water) całkowita woda ustroju

Table VI. Mean values and standard deviations (SD) of body water parameters measured using BIA in patients after HCT and healthy controls

Tabela VI. Wartości średnie i odchylenia standardowe (SD) parametrów gospodarki wodnej u pacjentów po HCT i zdrowych dzieci z grupy kontrolnej

\begin{tabular}{llll}
\hline $\begin{array}{l}\text { Parameter } \\
\text { Parametr }\end{array}$ & After HCT & Healthy controls & P value \\
Po HCT & Zdrowi & P & 0.171 \\
\hline TBW & $19.0[$ SD 4.21] & 20.5 [SD 4.42] & 0.406 \\
\hline LBM $(\mathrm{kg})$ & $61.3[$ SD 31.1] & $67.3[$ SD 27.6] & 0.039 \\
\hline ECW & $10.1[$ SD 3.96] & $13.3[$ SD 5.25] \\
\hline
\end{tabular}

ECW (extracellular water) woda zewnątrzkomórkowa; HCT (hematopoietic cell transplantation) przeszczepienie komórek krwiotwórczych; LBM (lean body mass) beztłuszczowa masa ciała; SD (standard deviation) odchylenie standardowe; TBW (total body water) całkowita woda ustroju

(ECW) in these groups of patients. To minimize the risk of measurement errors, all anthropometric parameters were measured by an expert anthropometrist employed in the Institute of Pediatrics.

\section{Bioimpedance measurements}

BIA measurements were performed in the morning, in a fasting patient placed in supine position, using multi-frequency $(1 ; 5 ; 50 ; 100 \mathrm{kHz})$ BIA 2000M analyzer (Data Input, Hofheim, Germany) using BIANOSTIC electrodes (Data Input, Poecking, Germany). The electrodes were placed in the same locations in all patients. The amplitude of measurement current was 0.8 $\mathrm{mA}$. In all patients BIA measurements were performed after 5-minute rest in the morning (8.00 am to $12.00 \mathrm{am}$ ). Body weight and height measurements were performed simultaneously.

\section{Statistical analysis}

Continuous clinical variables are presented as mean and standard deviation (SD) values. Categorical variables are presented as frequencies and percentages. The Shapiro-
Wilk test was used to assess the normality of continuous variables. To examine the differences between two/more than two independent groups Student's t-test/analysis of variance (for normally distributed variables) or the Mann-Whitney/ Kruskal-Wallis test (for non-normally distributed variables) was used. Two-sided P-values $<0.05$ were considered statistically significant.

Permanent Ethical Committee for Clinical Studies of the Medical College of the Jagiellonian University approved the study protocol. All parents, adolescent patients, and adult patients signed written informed consent before enrollment in the study.

\section{Results}

The differences in BF in patients before HCT compared with healthy controls were not significant ( $P$ value 0.912$)$, as were the differences in BF\% ( $P$ value 0.389). However, both $\mathrm{BF}$ and $\mathrm{BF} \%$ were significantly lower in patients after HCT 
compared with healthy controls ( $P$ value 0.008 and $P$ value 0.017 , respectively). The data are summarized in Tables I and II.

No significant differences in BMI, BMIPerc and BMISDS were found in patients before HCT compared with healthy controls ( $P$ value $0.17, P$ value 0.406 , and $P$ value 0.472 , respectively). The differences were also not significant for patients after HCT compared with healthy controls ( $P$ value 0.054 , $P$ value 0.108 , and $P$ value 0.263 , respectively). The data are summarized in Tables III and IV.

The differences in TBW, LBM and ECW in patients before HCT and healthy controls were not significant ( $P$ value $0.820, P$ value 0.427 , and $P$ value 0.886 , respectively). The comparison of patients after HCT and healthy controls revealed a significantly lower ECW in patients after HCT ( $P$ value 0.039 ) and no significant differences in TBW and LBM ( $P$ value 0.114 and $P$ value 0.105 , respectively). The data are summarized in Tables $\mathrm{V}$ and $\mathrm{VI}$.

No adverse effects of BIA measurements were reported.

\section{Discussion}

In our prospective analysis of patients treated with HCT we found reductions in body fat parameters in patients after HCT versus a control group of healthy subjects. This difference was probably due to the effects of HCT, and it was not paralleled by similar differences in classical parameters of obesity related to $\mathrm{BMI}$ value.

Patients treated with HCT experience various early and late effects of this procedure that may affect their health [9]. While early adverse effects, related to the transplantation procedure and graft-versus-host disease, are clinically evident and usually require immediate management, the late effects (LE) of HCT may develop over years and may need appropriate screening to avoid overlooking [10]. Nevertheless, LEs may severely affect the health status, quality of life and survival in patients treated with HCT [9].

MetS is a well-known LE reported in childhood cancer survivors [11]. In various studies, prevalence of MetS in patients after HCT was increased and ranged from $7.5 \%$ to as much as 32\% [1]. According to the IDF consensus, MetS is diagnosed on the basis of central obesity plus any two of the following: raised triglycerides, reduced high density lipoprotein (HDL) cholesterol, raised blood pressure, and raised fasting blood plasma glucose (or type 2 diabetes mellitus) [4]. MetS has a profound negative impact on general health, quality of life and survival of the patients [12-15]. This suggests that regular screening for MetS should be incorporated in the care of childhood cancer survivors with a history of HCT.

$\mathrm{BMI}$ measurements and calculations of BMl-derived parameters, such as BMIPerc and BMISDS, are simple and noninvasive methods that may be used for such screening [16-18]. However, in patients after HCT, the development of the metabolic aberrations typical of MetS in the absence of obesity defined on the basis of high BMI was reported. It was found that patients after HCT may have increased body fat and/or abnormal fat distribution even when their BMl is within the normal range [7]. This points to the need of using other screening methods beyond the traditional BMI-based parameters. This can be accomplished by confirming the accumulation of visceral fat that is typical of MetS, using such techniques as magnetic resonance imaging (MRI), computed tomography (CT) or dual-energy X-ray absorptiometry (DEXA) [19-21]. However, the use of these techniques in daily practice is limited by their cost and/or radiation exposure. This has led to the attempts to identify a simple, noninvasive method that can be used for the screening, and BIA has been implicated as such technique, with some promising preliminary results [22]. Our results confirm that the parameters obtained using BIA may reveal alterations of body fat that are not reflected in BMI or in related parameters. Moreover, our analysis of other body composition parameters revealed that in patients after HCT the ECW values were significantly lower than in healthy controls. Body composition measurements using BIA provide data on the muscle to fat proportion, which is of crucial importance. This is achieved using a four-surface electrode BIA technique at stable $50 \mathrm{kHz}$ frequency that provides information on ECW and its proportion to TBW [23]. Our own experience reveals that the HCT procedure is associated with major alterations in body water contents, most frequently in the form of fluid overload, which are seen within approximately one month after the procedure [author's unpublished data, on file]. In the present study we found that, 6 months after the procedure, body water content was markedly reduced. These events were probably caused by compensatory mechanisms.

Our study has limitations, mainly related to a relatively small group of patients, single-center design, and relatively short follow-up period, as components of MetS develop over years. Also, the study protocol included a limited number of parameters of body fat, while including other parameters like skinfold or waist circumference may have added more data to the analysis.

\section{Conclusion}

Our results suggest that patients treated with HCT should be screened for metabolic abnormalities associated with MetS, including alterations of body fat, and that the use of diagnostic methods other than routine BMl measurements may be justified. We found that BIA is a safe and noninvasive technique causing no adverse events, and we believe that it may be useful as a screening test in patients after HCT. To our knowledge, the literature lacks data on the use of BIA in this setting. Therefore, long-term studies including heterogeneous populations and longer follow-up periods are needed to confirm the possible role of BIA in the monitoring of patients treated with HCT. 


\section{References}

1. Bielorai $\mathrm{B}$, Weintraub $\mathrm{Y}$, Hutt $\mathrm{D}$ et al. The metabolic syndrome and its components in pediatric survivors of allogeneic hematopoietic stem cell transplantation Clin Transplant, 2017;31: e12903, https:// doi.org/10.1111/ctr.12903.

2. Adachi M, Oto $\mathrm{Y}$, Muroya $\mathrm{K}$ et al. Partial lipodystrophy in patients who have undergone hematopoietic stem cell transplantation during childhood: an institutional cross-sectional survey, Clin Pediatr Endocrinol 2017;26:99-108.

3. Cook S, Weitzman M, Auinger $P$ et al. Prevalence of a metabolic syndrome phenotype in adolescents. Findings from the third National Health and Nutrition Examination Survey 1988-1994. Arch Pediatr Adolesc Med, 2003;157:821-827.

4. International Diabetes Federation. 2006. The IDF consensus worldwide definition of the metabolic syndrome. https://www.idf.org/e-library/consensus-statements/60-idfconsensus-worldwide-definiti onof-the-metabolic-syndrome. Accessed on January 20, 2018.

5. Weiss R, Dziura J, Burgert TS et al. Obesity and the metabolic syndrome in children and adolescents. N Engl J Med, 2004;350: 2362-2374.

6. Otto-Buczkowska E, Dryżałowski M. Metabolic syndrome in young patients. Pediatr Endocrinol Diabetes Metab, 2015;23:32-36.

7. Armenian $\mathrm{SH}$, Chemaitilly W, Chen $\mathrm{M}$ et al. National Institutes of Health Hematopoietic Cell Transplantation Late Effects Initiative: Consensus Recommendations for Cardiovascular Disease and Associated Risk Factors. Biol Blood Marrow Transplant, 2016;23: 201-210.

8. Enomoto M, Adachi H, Fukami A et al. A Useful Tool As a Medical Checkup in a General Population-Bioelectrical Impedance Analysis. Front Cardiovasc Med, 2017; https://doi.org/10.3389/ fcvm.2017.00003.

9. Bhatia S, Francisco L, Carter A et al. Late mortality after allogeneic hematopoietic cell transplantation and functional status of long-term survivors. Report from the Bone Marrow Transplant Survivor Study. Blood, 2007;110:3784-3792.

10. Chow EJ, Anderson L, Baker KS et al. Late Effects Surveillance Recommendations among Survivors of Childhood Hematopoietic Cell Transplantation: A Children's Oncology Group Report. Biol Blood Marrow Transplant, 2016;22:782-795

11. Siviero-Miachon AA, Spinola-Castro AM, Guerra-Junior G. Detection of metabolic syndrome features among childhood cancer sunivors. A target to prevent disease. Vasc Health Risk Manag, 2008; 4,825-836
12. Cruz ML, Weigensberg MJ, Huang TT-K et al. The metabolic syndrome in overweight Hispanic youth and the role of insulin sensitivity. J Clin Endocrinol Metab 2004;89:108-113.

13. Wickham EP, Stern M, Evans RK et al. Prevalence of metabolic syndrome among obese adolescents enrolled in a multidisciplinary weight management program:clinical correlates and response to treatment. Metab Syndr Relat D, 2009;7:179-186.

14. Hu G, Qiao Q, Tuomilehto J et al. Prevalence of the metabolic syndrome and its relation to All-cause and cardiovascular mortality in nondiabetic European men and women. Arch Intern Med, 2004; 164:1066-1076.

15. Sarti C, Gallagher J. The metabolic syndrome: prevalence, $C H D$ risk, and treatment. J Diabetes Complications, 2006;20:121-132.

16. Barlow S.E. and the Expert Committee. Expert committee recommendations regarding the prevention, assessment, and treatment of child and adolescent overweight and obesity: Summary report. Pediatrics, 2007;120 (suppl 4):S164-S192.

17. Gregory J, Reilly J. Body Composition and obesity. Late effects of childhood cancer. Arnold Publication 2004;147-161.

18. The challenge of obesity in the WHO European Region and the strategies for response 2007 [online]. http://www.euro.who.int/_data/ assets/pdf_file/0010/74746/E90711.pdf Accessed on January 20, 2018.

19. Arif H, Racette SB, Villareal DT et al. Comparison of methods of assessing abdominal adipose tissue from magnetic resonance images. Obesity, 2007; 15:2240-2244.

20. Janiszewski PM, Oeffinger KC, Church TS et al. Abdominal obesity, liver fat, and muscle composition in survivors of childhood acute lymphoblastic leukemia. J Clin Endocrinol Metab, 2007;92: 3816-3821.

21. Wajchenberg BL. Subcutaneous and visceral adipose tissue. Their relation to the metabolic syndrome. Endocr Rev, 2000; 21: 697-738.

22. Drożdż D, Kwinta P, Pietrzyk JA et al. Wskaźnik masy ciała (BMI) czy analiza bioimpedancji elektrycznej (BIA) - która metoda pozwala lepiej ocenić zawartość tkanki tłuszczowej u dzieci? [Body mass index (BMI) or bioimpedance analysis (BIA)- which method enables a better assessment of fat mass in children?] Przegląd Lekarski, 2007;64(Supl 3):68-71.

23. Kyle UG, Bosaeus I, DeLorenzo AD et al. Bioelectrical impedance analysis part I: review of principles and methods. Clin Nutr, 2004; 23:1226-1243. 